\title{
The Study of Continuous Prosperity Problems Based on the Assessment of the Needs of Region's Economy in the Labour Force: According to Panel Surveys of Khabarovsk Krai Employers
}

\author{
M. Razumovskaya ${ }^{a}$, Zh.A. Ermushko ${ }^{\text {b }}$ * \\ * Corresponding author: Zh.A. Ermushko, ermu@mail.ru \\ ${ }^{a}$ Khabarovsk State Academy of Economics and Law, 134, Tikhookeanskaya str., Khabarovsk, 680042, Russia \\ ${ }^{b}$ Institute of Social and Humanitarian Technologies, National Research Tomsk Polytechnic University, 30, Lenina str., Tomsk, \\ 634050, Russia
}

\begin{abstract}
http://dx.doi.org/10.15405/epsbs.2016.02.64

The important issue of continuous prosperity identified as the assessment of the needs of economic entities in hired labor is examined in presented article. The subject of study is the combination of economic entities carrying out economic activity on the territory of Khabarovsk Krai. Authors consider that volumetric and structural characteristics of the needs correspond to the employer's need to have the necessary labour potential. In this case the need in the labour potential is specified by an organization's management as to the expected number of workers to a particular period of time. Authors received the assessment formulated by the employers in 2008 and 2013 according to the survey method on standard procedure. Specially designed questionnaire is used as an instrument of the survey. While composing there was an attempt made not to rely on the provisions of neoclassical theory, but on the political economy of the Austrian school of K. Menger, E. Böhm von Bawerk, F. Wieser. Employers' assessments that gave on opportunity not to rely on past trends, but on data about the excess and shortage of workers in certain categories in the future was transformed into a source of information for needs modeling of organizations in hired labour. Data on the subjective intentions of employers was summarized in the form of statistical models: by groups of economic activities and in the context of individual categories of employees. The result was presented in a medium-term forecast of use of labour resources. According to the 2013 survey it points to a continuation of the existing negative trens in the continuous prosperity of people employed in the economy.
\end{abstract}

C 2016 Published by Future Academy www.FutureAcademy.org.uk

Keywords: Need in hired labour, labour force, needs modeling of regional organizations, results of employers' survey, sample frame. 


\section{Introduction}

The need in labour force appears as a need of the subjects in the system of relations "individual employer" to have everything necessary for life. This need manifests as an objective relation between necessary and available things, thus we can talk about the satisfied needs and unsatisfied needs.

Based on neo-institutional theory and mathematical models of statistical estimation many researchers have attempted and continue to make attempts in assessment of unsatisfied needs in labor force of certain employers from the economy of the state and its administrative territories. Despite of the improved developed estimation tools only few researchers managed to get a satisfactory explanation of the results. For this reason the assessment of future labour force there was an attempt made to rely on political economy of the Austrian school of K. Menger, E. Böhm von Bawerk, F. Wieser. Its typical features was noted by V. S. Avtonomov (2004). They are the following: consistent and uncompromising subjectivism, strict methodological individualism, discreteness of analysis, critical attitude towards the possibilities of Mathematical Economics, review of Economics as a process occurring in real time. We want to recall that evolutionary school of economic mind mentioned above began its history in the XVI century when representatives of the Salamanca school in Spain developed the concept of a spontaneous order of human cooperation (Grice-Hutchenson, 1952). In accordance with it (unlike the neoclassical theory) theorems are not tested by empirical data. These theorems are deductively deduced from a priori provisions of human activity underlying the observed phenomena.

The present study began with the following premise: ways of adaptation of the employers to the environment and changes in their environment have the character of both conscious and unconscious actions in the formation and use of labour force. In our opinion to express these processes in measurable terms is possible only through surveys of economic entities providing job on a certain administrative territory.

\section{Experience in methodological and methodical support of hired labor demands prediction}

Information about perceptive organizations' demand in hired labor is a necessary basis for regulating spheres of economy both at macro and meso levels. Such information is used for developing prognoses of social and economic growth and monitoring its effectiveness. Experience in methodological and methodical support of hired labor demands prediction is represented both in domestic and foreign literature (Kuzminov, 2006; Marko, 2009).

Many researchers point that in foreign practice one can observe variety of approaches to predicting demands in hired labor. At the same time differentiation is a common thing in evaluation methodology fields of research- national and regional levels, sectoral and organizational levels, emphasis on combined needs components and peculiarities in their changes. The Bureau of Labor Statistics is the principal fact-finding agency in the field of labor economics and statistics in the USA. Labor statistics for 10-15 years ahead is checked up every 2 years and is a part of medium-term program on economic growth management.

In France prediction of hired labor demands within 5 year period is held by Labor Commission. According to the publications, in order to get information about future necessity in hired labor, foreign researchers combine expert, statistic and mathematical methods. Applying such methods scientists 
countrywide can determine value of each economic sector in employment. Then on the bases of dynamic model of sectoral balance and planned labor-force balance-sheet they figure the need in human resources.

The Russian Federation (RF) also has methods in determining and predicting the need in human resources. It is known that valuation of the need in human resources is necessary when policy is formed in education. Mutual development of economy and the system of professional education is not just a task to consider organizations' interests in human resources. Realization of this task gives a graduate a chance to build a professional career and life. Efficient organization of demand predicting process is a starting point that determines possibility in coordination of human resource development processes and development of sectors of economy.

Short review of methods of prediction of need in human resources, developed by Russian scientists is presented in table 1. It is clear that already described and other valuation methods of perspective need in human resources, presented in scientific literature, differ in levels of prediction specification and in indicators used for prediction analysis.

Table 1. Methods of evaluation and prediction of need in human resources

\begin{tabular}{|c|c|}
\hline Authors & Short review of methods \\
\hline $\begin{array}{l}\text { Savel'ev A.Ya. (Scientific-research Institute of Higher } \\
\text { Professional Education) (Gurtov, Pitukhin, Serova, 2007) }\end{array}$ & $\begin{array}{l}\text { Basic principles of formation of information and normative } \\
\text { prediction basis, economic and mathematical support and } \\
\text { software for multifactorial human resource demand modeling } \\
\text { are developed. }\end{array}$ \\
\hline $\begin{array}{l}\text { Gurtov V.A. (Petrozavodsk State University) (Gurtov, } \\
\text { Pitukhin, Serova, 2007) }\end{array}$ & $\begin{array}{l}\text { Experience of development of medium-term human resource } \\
\text { prognosis within administrative territory is presented. In } 2000 \text { a } \\
\text { group of researches analyzed demands in hired labor for some } \\
\text { Russian regions and got estimated human resource development } \\
\text { in the sphere of higher education in } 18 \text { branches. }\end{array}$ \\
\hline Sidunova G.I. (Sidunova, 2003) & $\begin{array}{l}\text { Method is based on coefficient of number of staff to changes in } \\
\text { production volume. It is assumed that there is a functional } \\
\text { dependence between these factors. }\end{array}$ \\
\hline $\begin{array}{l}\text { Alasheev S.Yu., Kuteinitsina T.G., Postalyuk N.Yu. } \\
\text { (Alasheev, Kuteinitsina, Postalyuk, 2004) }\end{array}$ & $\begin{array}{l}\text { Information basis for evaluation is results of survey of } \\
\text { employer enterprises about present-day and future number of } \\
\text { employees taking into consideration professions, specialty and } \\
\text { position. }\end{array}$ \\
\hline Popov A.D. (Popov) & $\begin{array}{l}\text { Methods of additional human resources demand predicting are } \\
\text { presented. Additional human resource demand is growing } \\
\text { demand because of appearance of new working places and } \\
\text { decrease in workers. }\end{array}$ \\
\hline $\begin{array}{l}\text { Kudel'ko A.R., Kotlyarov V.P., Yakovleva T.A., Vekrasova } \\
\text { M.G. (Kudel'ko, Kotlyarov, Yakovleva, Vekrasova, 2007) }\end{array}$ & $\begin{array}{l}\text { Variant of integrated system of economic and mathematical } \\
\text { predicting models of territorial human resource support systems } \\
\text { behavior is presented. Interaction model between labour-market } \\
\text { and educational market is offered. }\end{array}$ \\
\hline $\begin{array}{l}\text { Verbitskaya N.O., Matafonov M.E., Fyodorov V.A. (Gurtov, } \\
\text { Pitukhin, Serova, 2007) }\end{array}$ & $\begin{array}{l}\text { Expert and analytical model of multivariate prediction of } \\
\text { labour-market demand in workers is offered. Such model is } \\
\text { based on expert and analytical comparison of demographic } \\
\text { evolution tendencies, tendencies of technological development } \\
\text { of branches of economy (taking into consideration working } \\
\text { places), educational market development tendencies, } \\
\text { employment and unemployment dynamics. }\end{array}$ \\
\hline
\end{tabular}

Source: (Nigai, Boiko, Razumovskaya, 2009)

Methods of hired labor demands prediction, represented in scientific publications, contain various approaches to demands detection. Choice of the way of future demand in workers depends on prediction goals, peculiarities of informational basis, period of making prediction. Use of each method foresees certain assumptions and limitations, since each method has its own plusses and minuses.

Common disadvantage of all considered methods of workers demand prediction is inadequate understanding of "need in human resources" itself Gurtov V. (Gurtov, Pitukhin, Serova, 2007) and 
Popov A. (Popov) note in their works that "in present day Russian science (economy, demography, sociology, paleontology) there is no detailed and general term for hired labor demand". There is no state or departmental statistics by this indicator. That is why when trying to describe need in human resources, different organizations dealing with it, work with different close data.

It often happens that authors change "need in human resources prediction" to "labor demand prediction". It's proved by using such indicators as "employment", "human resources", "economically active population", "number of vacancies" and usually researchers estimate their changes in connection to production volume and structure. It means that received estimation serves as prediction of vacancies, employment or job placement for graduates. But the number of vacancies notified in placement service and executive search firms (they are also called additional labor demand), corresponds to the term "pent-up demand", and number of hired in economy which is also called "basic demand" is "filled demand" (Table 2).

Table 2. Classification criteria of hired labor demand prediction techniques

\begin{tabular}{|c|c|}
\hline Criterion & Criterion description \\
\hline Level of estimated parameter & $\begin{array}{ll}- & \text { Institution; } \\
\text { - } & \text { Branch; } \\
\text { - } & \text { Administrative territory; } \\
\text { - } & \text { State. }\end{array}$ \\
\hline Professional level of future staff training & $\begin{array}{l}\text { - } \quad \text { Higher professional education; } \\
\text { - } \quad \text { Vocational education; } \\
\text { - } \quad \text { Elementary vocational education. }\end{array}$ \\
\hline $\begin{array}{l}\text { Reasons for estimation of level of total hired labor } \\
\text { requirement }\end{array}$ & $\begin{array}{ll}\text { - } & \text { Work standards; } \\
\text { - } & \text { Real staff structure; } \\
\text { - } & \text { Real working places structure; } \\
\text { - } & \text { Real growth in number of specialists; } \\
\quad \text { Percentage of specialist leaving labor-market. }\end{array}$ \\
\hline Reasons for estimation of hired labor demand structure & $\begin{array}{ll}\text { - } & \text { Real staff structure; } \\
\text { - } & \text { Real vacancies structure; } \\
\text { - } & \text { Expected vacancies structure. }\end{array}$ \\
\hline
\end{tabular}

Source: (Nigai, Boiko, Razumovskaya, 2009)

We can make a conclusion that employer-organizations consider demand in hired labor to be a demand in labor potential supply able to increase economic assets in business activity (material and brain capital). In other words organizations' demand in hired labor characterizes employerorganizations' expectations in respect to quantity and quality of human resources. Only generated demand in labor can be particularized al the level of demand shown in labor market. It is expressed in definite employers' demand for professional and personal employees' qualities. It does not happen at the demand level.

We consider that in order to determine and predict demand in human resources implementation under conditions of high uncertainty in economic development of country and its regions we need expert methods of research. Taking into account that there is no officially published statistics about demand in human resources in that understanding which was offered earlier in that paper it is survey method to apply. A particular case of this method is expert survey where experts are heads of organizations (employers). 
http://dx.doi.org/10.15405/epsbs.2016.02.64

eISSN: 2357-1330 / Corresponding Author: Zh.A.Ermushko,Email: ermu@mail.ru

Selection and peer-review under responsibility of the Organizing Committee of the conference

\section{Data description}

As is known, the volumetric and structural characteristics of the labor force are formed in the joint and efficient use of production factors. We suppose that nobody can assess the needs of the organization in the intellectual and executing work better than employer. Solving the problem of its measurement, it is important to understand the following: adaptation methods of employers to the environment and changes in their environment are characterized as conscious and unconscious action in the formation of the labor potential.

In our opinion in order to express such processes into measurable indicators the examination of economic entities, providing the work on administrative territory could be made. In order to identify and assess Khabarovsk Krai economy needs in the workers and employees, heads of the organizations or their personnel departments were asked to complete the questionnaire, where the "question-answer" procedure is regulated. Next, we consider the contents of the questionnaire and compare the results of the survey held in 2008 and 2013.

The first part of the questionnaire contained questions about the legal ownership of the economic entity, the spheres of its primary and secondary activities, the administrative territory of functioning, as well as about the current support with workers.

In 2008261 organizations were selected, and in 2013 there were 237. Among all the organizations of the respondents, more than $90 \%$ was conducted business in the major cities of Khabarovsk Krai Khabarovsk and Komsomolsk-on-Amur. The total sample was dominated by enterprises of private ownership (in 2008 - 66.7\%, in 2013 - 79.3\%). Among respondents in 2013 there ware 12,7\% of the state organizations. This indicator is twice lower in comparison with 2008. In each period of the research, the number of enterprises with mixed ownership, and with the participation of foreign capital did not exceed $9 \%$ of the entire sample. All survey respondents were classified by types of economic activity in 8 groups (Fig.1).

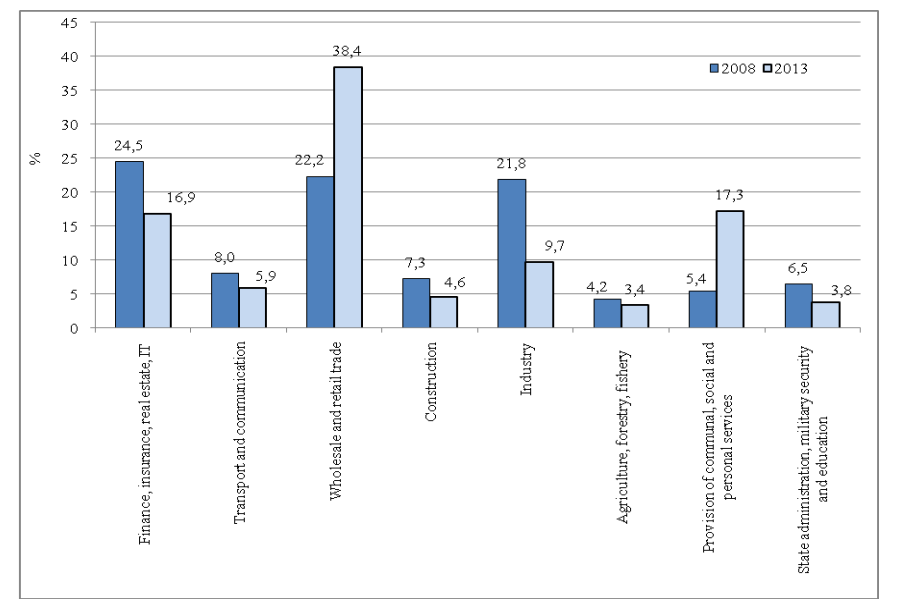

Fig. 1. Classification of Khabarovsk Krai organizations by types of economic activity (survey in 2008 and 2013) Source: authors' calculations

The total number of employees in 2008 was 98980, in 2013 - 11360. The largest share in the structure of employees was represented by professionals and skilled workers. Other categories of 
employees were slightly less. Managers and unskilled workers had an equal share in the structure. The variation in the number of employees in the enterprises of the Khabarovsk Krai was quite high. Respondents-organizations are classified as:

- $\quad$ very small, where the number of staff does not exceed 20 persons. Their share in the outturn in 2008 amounted to $28.7 \%$ and in 2013 to $16.9 \%$. This category was dominated by the organizations in trade sphere (in $2008-41.4 \%$ an in $2013-60.0 \%$ ), finance, real estate, information technology (in $2008-36.6 \%$, in $2013-15.0 \%$ );

- small, where the number of employees ranges from 21 to 100 persons. In 2008, they amounted to $31.4 \%$ of the total number of respondents, in 2013 the share was $41.4 \%$. Both of the research periods mainly were represented by trade organizations (in $2008-22.0 \%$, in $2013-33.7 \%$ ), finance, real estate, information technology (in $2008-25.6 \%$ and in $2013-17.4 \%$ ). In 2008, the organizations of industry (20.8\%), and in 2013 - communal, social and personal services $(24.5 \%)$ were also among them;

- medium, where the number of employees ranges from 101 to 500 persons. Their share in 2008 amounted to $25.7 \%$, and most organizations were from industry $(25.4 \%)$ and finance, real estate, information technology (15.0\%). In 2013, these respondents were $21.6 \%$. The dominant ones were representatives of the trade $(36.9 \%)$ and communal, social and personal services $(36.9 \%)$;

- large, where the number of employees is over 500 persons. In 2008, they amounted to $14,2 \%$, in $2013-20.3 \%$. The dominant ones in 2008 were organizations in the sphere of finance, real estate, information technology (13.6\%), transport and communication (13.4\%), and in 2013 dominant ones were spheres of trade $(27.1 \%)$, industry $(23.0 \%)$, communal, social and personal services (16.7\%).

In the chosen field of activity $57.9 \%$ of respondents in 2008 and $66.7 \%$ of respondents in 2013 functioned consistently (Fig. 2).

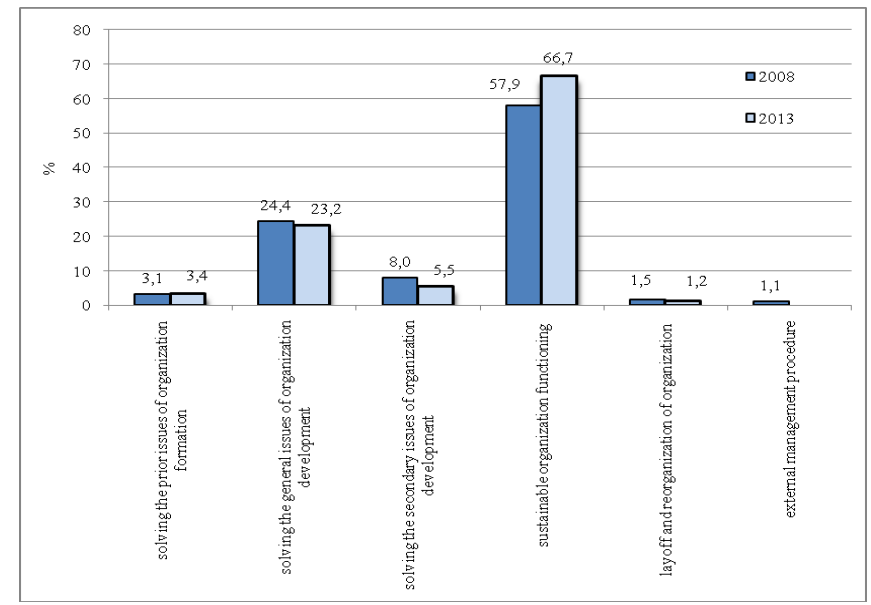

Figure 2. Classification of Khabarovsk Krai organizations by types of current issues to solve (survey in 2008 and 2013 ) Source: authors' calculations

Representatives of both research periods were:

- $\quad$ state administration, military security and education (in 2008 - 76.5\%, in $2013-88.9 \%$ ); 
http://dx.doi.org/10.15405/epsbs.2016.02.64

eISSN: 2357-1330 / Corresponding Author: Zh.A. Ermushko,Email: ermu@mail.ru

Selection and peer-review under responsibility of the Organizing Committee of the conference

- communal, personal and social services (in 2008-71.4\%, in 2013-97.6\%);

- $\quad$ construction (in $2008-57.9 \%$, in $2013-81.8 \%$ );

- $\quad$ finance, insurance, real estate, information technology (in $2008-57.8 \%$, in $2013-62.5 \%$ );

- $\quad$ industry (in $2008-56.1 \%$, in $2013-34.8 \%$ );

- $\quad$ agriculture, forestry, fishery (in $2008-54.5 \%$, in $2013-87.5 \%$ );

- $\quad$ transport, communication (in $2008-52.4 \%$, in $2013-71.4 \%$ ).

In 2008, 34\% of respondents focused on the solving of major and minor issues of their current development, in 2013 there were $28.7 \%$ of them. Among these respondents were such organizations as:

- $\quad$ industry (in $2008-42.1 \%$, in $2013-39.1 \%$ );

- $\quad$ wholesale and retail trade (in $2008-41.4 \%$, in $2013-44.0 \%$ );

- $\quad$ transport and communication (in $2008-38.1 \%$, in $2013-28.6 \%$ );

- $\quad$ construction (in $2008-36.9 \%$, in $2013-9.1 \%$ );

- $\quad$ finance, insurance, real estate, information technology (in $2008-35.9 \%$, in $2013-28.9 \%$ );

- communal, social and personal services (in $2008-28.5 \%$, in $2013-28.7 \%$ );

- $\quad$ in agriculture, forestry, fishery (in $2008-27.3 \%$, in $2013-12.5 \%$ ).

In each period of the research, a small part of the respondent-organizations focused on the priorities of economic management (in $2008-3.1 \%$, in $2013-3.4 \%$ ), as well as on the reduction of the activity or its reorganization (in 2008 to $2.6 \%$, in 2013 to $1.2 \%$ ).

The second part of the questionnaire allowed us to obtain information about the causes of the deficit or surplus of workers in connection with the implementation of events of operational and strategic character planned by employer, as well as information about changes in the future volume of need in hired labor in the context of economic activity.

The research revealed that every second respondent-organization had experienced a shortage of manpower. The reasons for this are shown in table 3 . The relevance of the following circumstances has increased for the period of 2008-2013:

- lack of workers of needed specialties on the local labor market (industry; construction; transport and communication; finance, insurance, real estate, information technology, state administration, military security and education);

- harsh (harmful) conditions (industry, construction);

- low salaries comparatively to the other companies (industry, construction, trade; communal, social and personal services).

- In the period of the research, every fifth respondent noted the surplus of labor resourses. The reasons for this are shown in table 3 . The surplus of workers is mainly associated with the following circumstances:

- high social responsibility of head of the organization (industry; construction; trade; transport and communication; finance, insurance, real estate, information technology);

- expectation of rising demand for manufactured products (construction; trade; transport and communications);

- $\quad$ high the costs of firing workers (state administration, military security and education); 
- other reasons (industry; trade; transport and communication; finance, insurance, real estate, information technology).

\section{Results of needs modeling in labour force according to panel surveys of Khabarovsk Krai employers}

Estimate of the needs in workers and employees was carried out as interpolation with the usage of approximating functions according to the method presented in paper (Nigai, Boiko, Razumovskaya, 2012). Its information is based on responses received from respondent-organizations for the basic year (year of survey), two subsequent interim periods (1-3 years and 4-6 years), final period (7 years or more). Trend models were obtained on the basis of MS Excel standard software.

Table 3. The causes of shortages and surplus of workers and employees in the organizations of Khabarovsk Krai

\begin{tabular}{|c|c|c|c|c|c|}
\hline \multirow{2}{*}{ Causes of shortages } & \multicolumn{2}{|c|}{$\begin{array}{l}\% \text { of respondent- } \\
\text { organizations }\end{array}$} & \multirow{2}{*}{ Causes of surplus } & \multicolumn{2}{|c|}{$\begin{array}{l}\% \text { of respondent- } \\
\text { organizations }\end{array}$} \\
\hline & 2008 г. & 2013 г. & & 2008 & 2013 г. \\
\hline $\begin{array}{l}\text { High costs associated with } \\
\text { employing workers }\end{array}$ & 15.3 & 9.1 & High costs of firing workers & 3.4 & 3.8 \\
\hline $\begin{array}{l}\text { Lack of workers of needed } \\
\text { specialties on the local labor market }\end{array}$ & 27.6 & 30.6 & Resistance of labor unions & 1.1 & 0.0 \\
\hline $\begin{array}{l}\text { High competition for workers in the } \\
\text { local market }\end{array}$ & 11.9 & 2.0 & $\begin{array}{l}\text { Limitations from the local (regional) } \\
\text { authorities side }\end{array}$ & 0.0 & 0.0 \\
\hline $\begin{array}{l}\text { Expectation of a reduction of } \\
\text { demand for manufactured products }\end{array}$ & 2.3 & 2.0 & Fears of conflict with the workforce & 3.1 & 0,0 \\
\hline $\begin{array}{l}\text { High turnover and (or) ageing of } \\
\text { staff }\end{array}$ & 21.1 & 2.0 & $\begin{array}{l}\text { Expectation of rising demand for } \\
\text { manufactured products }\end{array}$ & 8.4 & 9.6 \\
\hline Harsh (harmful) conditions & 10.7 & 35.0 & $\begin{array}{l}\text { Social responsibility of the head of the } \\
\text { organization }\end{array}$ & 10.7 & 30.8 \\
\hline $\begin{array}{l}\text { Low salaries comparatively to the } \\
\text { other companies }\end{array}$ & 17.6 & 19.0 & Other reasons & 4.2 & 40.4 \\
\hline Other reasons & 11.5 & 0.3 & & & \\
\hline
\end{tabular}

Source: authors' calculations

According to panel surveys in 2008 and 2013 in the course of modeling the overall need in workers and employees of Khabarovsk Krai organizations was estimated. As follows from figure 3, in both cases it tends to grow, but the rate of change varies considerably. According to a survey in 2008, to 2021-2023 it is expected more than ten-fold increase in the overall need in workers. According to the survey in 2013 the increase in the overall need in workers to 2023-2025 should be about $41.3 \%$. Thus, between two research periods heads of organizations have significantly revised the plans of their business activities on the territory of Khabarovsk Krai. We emphasize that optimism rate has become significantly lower.According to panel surveys in 2008 and 2013 in the course of modeling the need in the workers and employees for each category of economic activities in the context of individual categories of workers of Khabarovsk Krai organizations was also estimated.

As we can see, in agriculture, forestry and fishery the overall need in workers and employees by 2025 will increase in 1.35 times compared to the current need in 2013. Upon that there is a high demand for employees - on average it is equal to $41 \%$ of its total value. The need for specialists is less on average it is $18 \%$ and it is increased by $2.2 \%$ (from $16.4 \%$ to $18.6 \%$ ). Among workers staff there will be an increasing demand for skilled workers, which on average is about $18.7 \%$ of overall need. 
http://dx.doi.org/10.15405/epsbs.2016.02.64

eISSN: 2357-1330/Corresponding Author: Zh.A.Ermushko,Email: ermu@mail.ru

Selection and peer-review under responsibility of the Organizing Committee of the conference

The need in unskilled workers and head staff differs slightly, and its share is on average of $9.2 \%$ and $13.1 \%$ correspondingly.

The industry is projected significant growth in overall need. In the last forecast period it will increase by 2.2 times in comparison with the basic year. The structure of need is concentrated on the category of "workers" and more of skilled ones, the share of which on average is about $45.7 \%$. And share of needs in unskilled workers in general structure of industry will be reduced from $2.4 \%$ in 2013 to $1.2 \%$ by $2023-2025$. During the same period, the demand for employees in overall increases from $4.0 \%$ to $4.5 \%$, head staff - from $8.3 \%$ to $15.4 \%$, specialists - from $18.3 \%$ to $25.6 \%$.

In the construction sector the situation in composition and structure of staffing needs will remain fairly stable. The employees prevail in the overall need. Their share in average amounts to $59.4 \%$ of the total volume. Head staff and specialists correspondingly have an average of $15.3 \%$ and $6.2 \%$ of the overall need. The need for head staff is growing slowly and by $2023-2025$, its share in the overall rate will be reduced to $14.8 \%$. The need in specialists and unskilled workers is rather low. To 2023-2025 the share of specialists will grow by $0.8 \%$ in comparison with the need for the basic year and the share of unskilled workers will not change. The need in skilled workers will increase from $14.6 \%$ to $15.1 \%$.

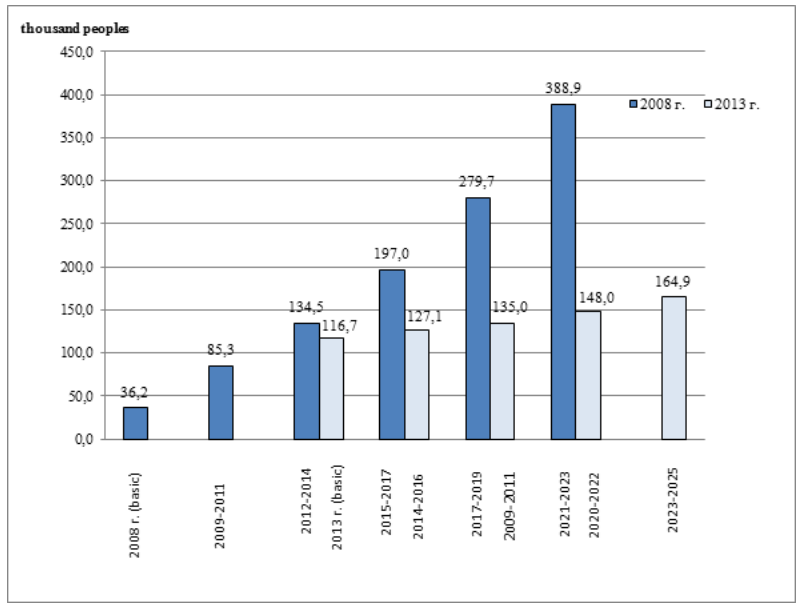

Figure 3. Estimate of the overall needs in the workers and employees of Khabarovsk Krai organizations on the basis of the trend models, obtained according to panel surveys. Source: authors' calculations

In the structure of the labor needs in commercial workers the need in skilled workers is about $33 \%$. On average the need for head staff may be $7.1 \%$, for specialists $-25.4 \%$ and for employees $-24.7 \%$. During the research period there will be changes in each category of workers. Compared to the basic year, by 2023-2025 the level of demand for skilled workers and unskilled workers will be reduced from $36.1 \%$ to $35.5 \%$ and from $13.8 \%$ to $6.9 \%$ correspondingly. It will grow for the head staff $(2.1 \%)$, specialists (2.0\%) and employees (3.5\%).

By 2024 overall needs in hired labor for transport and communication organizations in Khabarovsk Krai will increase by 4.5 times compared to 2008. Mainly this is determined by increased demand in two categories: "specialists" - by $16.4 \%$, "other employees" - by $15.1 \%$. In the category of "head staff" in the structure of overall need there is a decrease from $41.3 \%$ to $10.8 \%$. Share of need in workers in its overall structure will not change and will be $28 \%$ for skilled workers and $1.2 \%$ for unskilled ones. 
By "finance, insurance, real estate, information technology" category of economic activity the overall need in manpower will increase in more than 11 times. This is where the share of need in skilled workers increases from $6.8 \%$ to $80.7 \%$ in the overall structure of needs. The share of needs in other categories of workers in the overall structure is reduced, except for the needs in head staff whose share is almost the same.

In "state administration and education" category it is noted the significant increase in overall need by 2024. In absolute terms it should increase from 471 persons in the basic period to 138763 persons in the last forecast period. This is where the highest increase in the share of head staff and skilled workers in the structure of overall need is expected.

\section{Conclusion}

Economic entities of Khabarovsk Krai are at different stages of development and differ in both the number of employees and structure. Their current need in hired labor is $16 \%$ of total employment in the economy of the region. This is almost twice less than the number of unemployed and graduates of institutions of basic, secondary and higher education combined in total. Assessment of future needs indicates a continuation of the existing negative trends in the continuous prosperity of people employed in the economy.

\section{Acknowledgements}

The study was conducted at Federal State Budgetary Educational Institution of Higher Professional Education «Khabarovsk State Academy of Economics and Law» with financial support of Ministry of Education and Science of the Russian Federation in the framework of the scientific research contract № 1929. The authors would like to thank the anonymous referees for their constructive and useful comments on the paper.

\section{References}

Avtonomov V. S. (2004) History of economic studies. Study book edited by V. Avtonomov, O. Ananyina, N. Makasheva/ Moscow, INFRA-M Publ., pp. 186-188.

Grice-Hutchenson M. 1(952) The School of Salamanca, Reading in Spanish monetary theory. Oxford: Clarendon Press.

Gurtov V.A., Pitukhin E.A., Serova L.M. (2007) Verification of macro economical method of predicting demand in qualified workers through the analysis of graduates' job placement and placement services vacancies. / Demand and supply in labour-market and educational market in Russian regions: collection of articles based on materials from the Fourth All-Russian research and practice international Internet conference. Book 1 Petrozavodsk.

Sidunova G.I. (2003) Regional human resource policy: innovative approach. Volgograd, (electronic resource). http://www.smartcat.ru/Personnel/

Alasheev S.Yu. (2004) Methods of mid-term prediction of demand in human resource development in the system of professional education in a region / Alasheev S.Yu., Kuteinitsina T.G., Postalyuk N.Yu. Demand and supply in labour-market and educational market in Russian regions: collection of articles based on materials from All-Russian research and practice international Internet conference. Petrozavodsk.

Alasheev S.Yu., Kuteinitsina T.G., Postalyuk N.Yu. (2004) Methods of mid-term forecast of staffing needs in the economy of the region. Samara, «Profi» Publishing house.

Popov A.D. Economy demand in specialists and qualified workers: methodical basis for predicting. Available at: http://www.rhr.ru/index/jobmarket/russia/8035,0.html.

Kudel'ko A.R., Kotlyarov V.P., Yakovleva T.A., Vekrasova M.G. (2007) System of territorial human resource support in modern economic conditions. Vladivostok, Dalnauka Publ.

Nigai E. A., Boiko T. S., Razumovskaya M. I. (2012) Review of Methodological Approaches to Prediction of Organizations' Needs in Human Resources. The journal «North-East Asia academic Forum» (Publication of scientific articles). Kazakhstan, «Kainar» (Semey) University, pp. 96-98. 
http://dx.doi.org/10.15405/epsbs.2016.02.64

eISSN: 2357-1330 / Corresponding Author: Zh.A.Ermushko,Email: ermu@mail.ru

Selection and peer-review under responsibility of the Organizing Committee of the conference

Kuzminov Y. I. and others (2006) Origins. On the experience of study economy as a structure and process / editors. : Y. I. Kuzminov.; State University - Higher School of Economics. Moscow, Publishing house SU HSE.

Marko D.V. (2009) Predicting regional demand in human resources with professional education, abstract from a thesis of Ph.D. in economics. Irkutsk. 24pp. 